\title{
Tax Incentive Policy Evaluation on Donation for Disaster Charity in Indonesia
}

\author{
${ }^{1}$ GALUH AYU WASILAH, ${ }^{2}$ MARIA R.U.D. TAMBUNAN \\ 12 Department of Fiscal Administrative Science, Faculty of Administrative Science, \\ University of Indonesia, Indonesia, Depok West Java Indonesia, 16424 \\ email: ${ }^{1}$ galuhwasilah@outlook.com; ${ }^{2}$ maria.tambunan@ui.ac.id
}

\begin{abstract}
This research is conducted to evaluate tax incentives for donation activities of disaster management based on policy evaluation criteria by William Dunn which consists of effectiveness, efficiency, adequacy, equity, responsiveness, and accuracy. The research method used is qualitative approach and qualitative data analysis techniques. In qualitative research, the researcher occupied theory as a tool to guide the research by collecting data through interviews and literature study until reaching the conclusion. The data used in this research is qualitative data, gathered through literature review, documentation study, and in-depth interviews with experts (policymakers, policy implementers, academicians, civil society). The result of this study indicates that the tax incentive policy on donations for disaster management has not met William Dunn's policy evaluation criteria. The research shows that quite limited benefit granted and less clear of technical guidance of tax incentives implementation for disaster donations lead the taxpayer which has been undertaking the role as donators to not utilize the incentives. In order to occupy tax incentives to contribute to disaster management effectively, the government needs to socialize the implementation with clear guidance.
\end{abstract}

Keywords: tax policy evaluation, tax incentives, donation

\section{Introduction}

Tax incentive policy on philanthropic activities to support disaster response is one of the important elements for the development of the philanthropy organization sector in Indonesia. The existence of these organizations in Indonesia is very crucial since the country is in the pacific ring of fire where $75 \%$ of active volcanoes are in this circle and extremely prone to natural disasters, especially earthquakes and tsunamis. According to the World Risk Report 2018, Indonesia is categorized as a country with high risk to disaster, ranked 36th among 72 countries with 10.36 index score out of 100 (Heintze, 2018). This index does not only indicate a higher risk to natural disaster incidents, but also the social vulnerability to the disaster.

Nevertheless, natural disaster incidents have somehow trained the citizens of Indonesia to be more alert and responsive to disaster. The disaster also leads to various disaster response or humanitarian activities, such as providing aid to relieve the loss of the victims. The relief works do not only come from the government but also initiated by the citizens and companies (Brown et, al. 2016) The distribution of donation also comes in various ways, directly by the citizens or companies to the victims of the disaster as well as through disaster response agencies. The activity of delivering donation is a type of philanthropic activity. National Disaster Response Body also confirms that the natural disaster in Indonesia has been fluctuating in the past 10 years, but still on over-all increase trend with approximately 1000 to 2500 disaster incidents occurring each year. Due to the large number of incidents in the past ten years, a natural disaster has no longer

Received: 2019-08-17, Revised: 2019-10-20, Accepted: 2019-12-28 
considered as a force majeure in Indonesia (The World Bank, 2012).

According to the World Giving Index survey by the Charities Aid Foundation (CAF), Indonesia is the number one among the 146 countries with the score of 59 out of 100 as the most generous country in 2018 (CAF, 2018:11). This score means $59 \%$ of the total population in Indonesia has conducted a philanthropic activity indicated by the habit of donating money, helping others, and voluntary activities. In other words, Indonesia has a large potential for philanthropic activities, including helping the government in disaster relief works.

The role of philanthropic activities in disaster response works has encouraged the government to formulate regulation to support the companies or philanthropic organizations to continuously engaged in disaster response work. One of the regulations was released in 2010 to provide a tax incentive to philanthropic activities. The incentive scheme is considered could encourage the citizens to continuously do the activities that are expected by the government by providing a reward to anyone that continuously doing such activities (Darussalam, 2017:3).

The types of tax incentives for income tax on donation are categorized into two types, i.e.; tax exemption and tax deduction. Tax exemption is given to donation or income generated from a non-profit organization, which can be excluded from the object of the income tax. The tax deduction is given to the individual donors or corporates which are used as a reduction to the gross income. This tax incentive become one of the government facilities to carry out its government functions in terms of taxes, namely function as source of safe and inexpensive and sustainable revenue, instrument of justice and equity, instrument of development policy, instrument of employment, and instrument of climate change mitigation and adaptation (EFA, 2018:3).

To state a disaster as a national disaster, it is necessary to pass certain considerations regulated in Disaster Management Law Number 24 year 2007. The law states that the determination of the status and level of national and regional disasters is based on indicators of the number of victims, loss of property, damage to facilities and infrastructure, the extent of area that affected by disaster, as well as social-economic impacts that caused.
The tax incentive has various advantages if designed properly, measurable, and directed to a good target. The tax incentive could provide a positive contribution to the economy and society. In the economic aspect, the tax incentive contributes to the increase of the investment volume. Meanwhile, in the social aspect, the tax incentive will contribute to the behavioral changes of the citizens to participate in activities (Hickey, et., al, 2019). The tax incentive for philanthropic activities is expected to accelerate the collection of donations since donating is an elastic activity which is highly influenced by the regulation (Darussalam, 2017:8). In the implementation, there are at least three main actors in tax incentives for donation of disaster management: government, donors, and donation organization.

Philanthropic activities in Indonesia are growing in response to the higher frequency of natural disaster occurrences with larger scale and impacts. However, the tax incentive on donation for disaster response works can only be granted to reduce the taxable income if the donation is directed to the national disaster category ("kategori bencana nasional"). This has led to a polemic since the donation for disaster response work has also contributed to the higher philanthropic activities that help the government during the post-disaster recovery. The national disaster category is decided considering particular conditions and the regulation. Meanwhile, until the end of 2018, the last disaster that was categorized as a national disaster was a tsunami incident in Aceh in 2004. Considering the description above, to understand the tax incentive regulation on donation activities for disaster response work, the research problems in this paper are (i) How is the analysis of tax incentive regulation on donation activities for disaster response work in Indonesia and (ii) How is the evaluation of the tax incentive regulation on donation activities for disaster response work in Indonesia. This research is expected to contribute to the development of tax incentives policy in Indonesia toward the supporting of entities which contribute to charitable and philanthropic activities.

\section{Research Methodology}

This research uses a qualitative approach that is intended to analyze social issues through a deep understanding of the problems. The research occupies a qualitative method to explore the phenomenon and to 
understand the underlying factors lead to the existence of the phenomenon. Thus, following the research method selected, the objective of this research is to provide a specific overview of the condition, phenomenon or social indications on the implementation of tax incentives for donation allocation for disaster management in Indonesia. Qualitative methods are stressed within the qualitative paradigm not because the paradigm is antiquantitative but because qualitative methods come friendly to the human as an instrument and the considerably appropriate method to descriptively explain the human-related situation (Cropley, 2019). According to the timeframe of the research, this research is cross-sectional research since it is conducted in a specific particular period. Cross-sectional research is any research that examines information in many cases at one point in time (Newman, 2014:44). This is in accordance with the period for this thesis research, which from January 2019 to June 2019.

This research used qualitative data gathered as primary and secondary data. The primary data was gathered from an in-depth interview with the experts related to the subject discussed in this field of study, whereas the secondary data was gathered through literature review and documentation study. The in-depth interview has been undertaken with various parties, i.e. Directorate General of Taxes (DJP), philanthropy practitioner, Fiscal Policy Office, disaster management experts, tax practitioners, and the taxpayers. Then, for the purpose of secondary data collection, it has been undertaken the information gathering from books, articles, prevailing rules, and electronic publications. Further, the researcher performed data analysis technique based on qualitative technique, which after collecting data, the next step is to analyze the data by interpret the result of field studies and literature studies relating to disaster tax incentive and look for similar pattern from data related to its theme to find things that can be studied and used to analyze the problem. Important to note that since this research is qualitative, it could not be applied immediately to a similar situation since the research is conducted on a caseby-case basis.

\section{Results and Discussion Policy Evaluation}

Policy evaluation is defined as "careful retrospective assessment of the merit, worth and value of administration, output, and outcome of government interventions, which is intended to play a role in future practical action situations" (Schoenefeld and Jordan, 2017). William Dunn in 1994 developed 6 (six) indicators of policy evaluation criteria as key functions in policy analysis. Evaluations provide valid and reliable information regarding the performance of a policy that has been achieved through public action. Table 1 shows the evaluation criteria proposed by William Dunn.

\section{Table 1 \\ William Dunn's Policy Evaluation Criteria}

\begin{tabular}{ll}
\hline CRITERIA & QUESTIONS \\
\hline Effectiveness & Have the desired results been achieved? \\
Efficiency & How much effort is needed to achieve the desired \\
& results? \\
Adequacy & $\begin{array}{l}\text { To what extent has the desired outcome been able to } \\
\text { solve the problem? }\end{array}$ \\
Equal distribution & $\begin{array}{l}\text { Are costs and benefits distributed evenly to certain } \\
\text { groups of people? } \\
\text { Do the policy results satisfy the needs, preferences, or } \\
\text { Responsiveness } \\
\text { values of certain groups? } \\
\text { Do the policy results satisfy the needs, preferences, or } \\
\text { Responsiveness } \\
\text { values of certain groups? } \\
\text { Accuracy } \\
\text { Are the results achieved useful and truly useful/ } \\
\text { valuable? }\end{array}$ \\
\hline
\end{tabular}

Source: Dunn (2003)

\section{Tax Incentives and Tax Expenditure}

On OECD Documentation (2014) regarding the fundamental principle of tax policy, it states that the tax function is divided into 2 (two) broad categories: as a source of sustainable state revenue and as a sociopolitical instrument. Tax as a socio-political instrument is used by the government to achieve certain goals that have been set. The tax could be used as an instrument to encourage or to inhibit activity. But in essence, the tax is applied as the instrument toward the sustainability of the country and the welfare of its people (Wilson-rogers and Pinto, 2009). The tax as a political instrument can be elaborated in several functions, among others (Rosdiana and Irianto, 2014: 45): (1) The Function of Tax as a Sustainable Source of State Revenue; (2) Tax Function as an Instrument of Justice and Equity; (3) The Tax Function as an Instrument of Development Policy; (4) The Tax Function as an Employment Instrument; (5) The Tax Function as an Instrument of Climate Change Mitigation and Adaptation Policy.

The tax incentives can be defined as all forms of incentives that reduce corporate tax burden with the aim of encouraging companies to invest in certain sectors or projects in order 
to boost the growth (Sari et.al, 2015). Usually, this tax incentive is given with the intention of thriving the country's economy, especially in developing countries. The provision of tax incentives can stimulate investors to invest their capital so that incoming investment can increase economic growth and people's welfare. United Nations (2018) stated the types of tax incentives, in general, include tax holidays, investment allowance and tax credit, timing differences, and reduced tax rates and other types of favorable tax treatment to reduce the tax burden. Most of the time, the provision of tax incentives will cause tax expenditure. A tax expenditure is one form of loss of potential taxation or more precisely the potential revenue that is sacrificed by the government by providing some form of tax relief as an instrument of fiscal policy to achieve certain goals set by the government for economic and/or noneconomic purpose (Redonda et.al, 2018, 4). In its implementation, tax expenditure has various forms including exemption, reduction, credit adjustment, and tax deferral (Redonda et., al, 2019).

At the moment, the tax regulation that is directed to the disaster issue is the Act No. 36 the year of 2008 which covers the discussion on donation for disaster response that can be excluded and/or reduced from the taxable income, particularly stated in Article 4 paragraph (3) alphabet a for the tax exemption and Article 6 paragraph (1) alphabet for tax reduction.

\section{The donation as a Non-Taxed Object Regulation}

According to PMK No. 245 the year of 2008, the tax exemption object is the donation received by social organizations including cooperation, which activities are mere to initiate activities, one of them including donating to the disaster victims and does not look for any profit. Looking at these rules, a donation can be categorized as a non-taxed object if it is received by the non-profit social organization. In Indonesia, a non-profit organization can directly receive tax exemption if the income they received is not taxable. Substantially, each income received by the non-profit organization as indicated in the PMK 245 the year of 2008 is considered as a pass-through and can directly be considered as a non-taxable object. Moreover, the regulation does not mention the criteria of the disaster that can be used as an exclusion to be eligible as a non-taxable recipient. In other words, the recipient of the donation can use the donation as a tax exemption for any disaster, and not limited to the national disaster status.

However, the regulation on the tax exemption as mentioned in the Income Tax Act, as well as Minister of Finance Regulation and its derivatives, does not regulate the mechanism if the donation object comes from foreign countries. The absence of the rules for this issue could prevent legal security in taxation. As it is stated by Rosdiana (2014:168), without a clear procedure, it will be difficult for the taxpayer to fulfill their obligation and receive their rights. It will be also difficult for the tax officer to monitor the tax obligation implementation by the taxpayers. Sommerfeld in Rosdiana (2014:168) also states that detailed guidelines for tax collection, advanced ruling, and other law interpretations are required to ensure legal security. In addition, the lack of proper and adequate rule of tax incentives will lead to ambiguity. Once the audit of the use of tax incentives undertaken, the submission to tax compliance rules would be another new challenge (Yoon et., al, 2011).

Other regulation on the tax exemption object states that donation could be used as a non-taxed object if the donors do not have a business relationship, works, ownership, or control over the beneficiaries. This regulation has raised different responses from the Indonesian Philanthropy Association, stating that the oldest philanthropy organization in Indonesia that currently growing is a family foundation. Rules on the tax exemption limit on the organization that has a relationship with the donors are regulated in the Income Tax Act article 18 verse (3) and (4). The objective of this limitation is to prevent any tax avoidance practice due to a special relationship.

Similar to the other corporate entity or individual taxpayer, a non-profit organization also has a tax obligation, such as collecting, transferring, and reporting their tax obligations through a self-assessment system. Moreover, the non-profit organization also prepare their financial report with a particular format for non-profit organization financial form in Indonesia following the Statement of Financial Accounting Standard (PSAK) No. 45 the year of 2000, covering a financial balance at the end of the year of reporting period, report on activities as well as cash flow and financial 
reports.

\section{Rules on Donation as a Tax Exemption}

On the donation for disaster response, as stated in PMK No. 76 the year of 2011, the tax reduction object is defined as a donation for national disaster response works. It should be noted that the donation could be used to reduce the tax obligation only if the donation is targeted to any national disaster response works. If the natural disaster has been officially stated by the respective government body as a national disaster, disaster management no longer follows the instructions under the regional government (or local government) where the disaster occurred as the main government body which is responsible for the organization of disaster relief. Further, the central government would be the leading of disaster relief. The national disaster could be decided in two ways. First, it could be decided through a written statement by the local government stating that they are no longer capable to respond to the impacts of the disaster, and second, the determination of disaster status might directly be taken care by the national government if the conditions have fulfilled the Act No 24 the year of 2007 on disaster response. On the other hand, if the disaster has been categorized as a national disaster, the local government where the disaster took place will lose their authority to do the disaster response work and all the authority and control on the disaster response will be directed to the central government.

According to PMK 76/2011, the amount of donation donated by the entities taking action as donors that can be used to reduce the gross income is limited to a maximum of 5 percent of the net income after tax of the previous tax year. Generally, there is a pattern to decide the amount of tax reduction, i.e.: full deductibility, limited deductibility, and tax reduction that is probably greater than the amount given. However, the amount of granted tax reduction depends on the 'targeted subject' decided by the government. The previous research (Blumenthal, Kalambokidis\& Turk, 2012) on the tax subsidy relating to donation is calculated based on the amount of donation given by the donor. For the Indonesia case, the donation for disaster response is categorized in limited deductibility if it follows the 5 percent limit.

In limited deductibility, the government sets a limit to the amount of donation from the income that can be used to deduct the taxable income. The government does not limit the amount of donation from the donors, but the government provides tax incentives following the amount of donation with a certain maximum limit. The limited deductibility is applied to prevent the donors from using their funds to avoid the tax or perform unlawful contributions (Fack and Landais, 2011).

Meanwhile, the subject of the donation that can be deducted from the taxable income is the organization or individual who donates to the victim of disaster through particular organizations. The donation can be used to deduct the tax if it is delivered directly through disaster response organization or indirectly through an institution or party that has a permit from the authorized institution/organization to collect the disaster response donations. In Act No. 24 the year 2007, disaster response organizations are the National Institution for Disaster Response (BNPB) and Regional Institution for Disaster Response (BPB-D). Meanwhile, if the donations are delivered indirectly, it should be delivered through an authorized institution or party, that is the institution that has been granted a permit from the Ministry of Social to collect the donation for disaster response. It means the benefit of tax incentives could be granted if the money donated by the donors goes to certain organized which assigned by the Indonesian government. The similar tax incentives might be inapplicable if the personal/entities acting as donors could not fulfill the requirement as regulated by the government. It might argue that there will be a possibility whereby the donor would lose the ability to get tax incentives when they act as direct donors (John Brooks, 2016).

\section{Discussions}

The tax incentive evaluation is conducted by using the theory of evaluation by William Dunn. This research uses six evaluation criteria delivered by Dunn, i.e.: effectivity, efficiency, adequacy, equity, responsiveness, and appropriateness respectively.

\section{The Tax Incentive Evaluation on Donation for Disaster Response According to the Effectivity Criteria}

As mentioned above, the researcher uses the evaluation criteria from William Dunn, and the first criteria is effectivity. Dunn (2003) stated that a policy is considered effective if the expected outcomes have 
fulfilled the expected goals. The objective of the tax incentive policy on donation for disaster response is to improve the citizen's participation during the disaster response. To ensure that the successful implementation of this policy, the government released PP No. 93 the year of 2010 and PMK No. 76 the year of 2011 as implementation regulation on the guidelines for national disaster donation registration and reporting.

However, in fact, based on the interview to the targeted entities, the tax incentive policy is not accessible for the taxpayers who donate for the disaster victims since the publication of the policy until currently. The policy becomes unusable due to the requirement that the tax incentive policy is only applicable in the case of national disaster status. This quite rigid rule leads to huge numbers of ineligible donators who inherently should be able to get the benefit of applying tax incentives. The less optimal used of tax incentives to some extent is caused by the complexity of the benefit offered. This complexity leads to a passive reaction of targeted entities (Abeler and Jager, 2015). Looking at the current condition, the Indonesian citizen's participation to donate is considerably increasing, indicated by the increase of the percentage of the number of people who donate according to the survey by Charities Aid Foundation (CAF, 2018) even in the less occupied tax incentives.

\section{Table 2 World Giving - Donating Money Index}

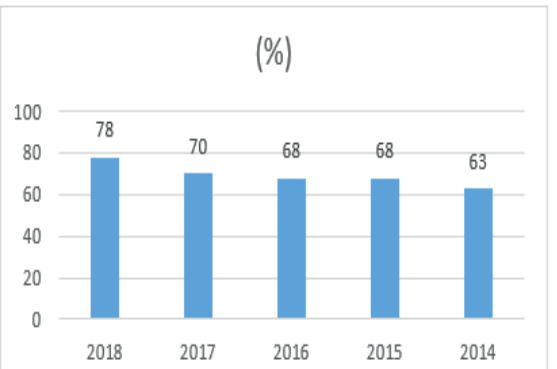

Source: Charities Aid Foundation, data processed by the author, 2019.

In addition to the data presented in Table 2., the author also obtained data from the Directorate General of Taxes when conducting in-depth interviews with regard to the participation of donation prior to the relief of disaster in Indonesia. The information is set out in the Table 3.

The Table 3 shows the amount of total donation of CSR (Corporate Social Responsibility) gather from non-individual entities. The data does not include the amount of donation from the citizens for the victims of disaster, due to the limited data acquired by the author of this research. The table and the graphs indirectly indicate that the Indonesian companies have sufficiently large potential for philanthropic activities, looking at the amount of donation or the increasing number of donating activities. Although the citizen's participation has increased, this is not the impact of the tax incentive policy since the incentive has not been accessible. It rather indicates there are other factors outside the tax incentive scheme that has influenced the citizens' behavior to donate.

Table 3

\section{Recapitulation The Amount of} Donations

\begin{tabular}{lc}
\hline \multicolumn{1}{c}{ Year } & Amount of Donation (IDR) \\
\hline 2016 & 22.721 .185 .639 \\
2017 & 46.169 .356 .480 \\
2018 & 19.902 .443 .905 \\
2019 (triwulan I 2019) & 507.416 .000 \\
\hline Total & $\mathbf{8 9 . 3 0 0 . 4 0 2 . 0 2 4}$ \\
\hline \multicolumn{2}{c}{ Source: Directorate General of Taxes (2019) }
\end{tabular}

The fact that the incentive policy is limited by the national disaster status also implies that the government has not sufficiently given their concern to the potential of the citizen's participation in disaster response works through the donation. The government decided to give the national disaster status by referring to Act No. 24 the year 2007 on Disaster Response. The national/regional disaster status and level are determined by considering the following indicators: (a) the number of victims; (b) material loss; (c) infrastructure damages; (d) area affected by the disaster, and (e) socioeconomic impact.

Following that regulation, the central and regional governments are responsible for and have the authority to conduct disaster response works with the help of BNPB. Other policies to define the status and level of the disaster besides the aforementioned indicators, is regulated by the Presidential Regulation following the disaster incident. The indicators for defining the national disaster status that are stated in the Act No. 24 year of 2007 on disaster response, depicts that the Act is still problematic since it does not mention the number of victims and the loss as well as 
the scale of the socio-economic impacts for a disaster to be categorized as a national disaster. This has also led to debate since there are no clear and detailed rules to define the national disaster status. Eventually, the determination of the national disaster status should receive the President's approval. This quite complex prerequisite to determine the status of disaster indirectly add to other complexity of granting tax incentive and how it should take to manage and organize the activities to relieve the disaster (Kurniati, 2015).

In general, the Disaster Response Act only provides five indicators to define the status of the disaster. However, cited from the Head of the Center of Data, Information, and Public Relations Sutopo PurwoNugroho, besides the five indicators mentioned above, there is another indicator for the government to define the national disaster status, i.e. the function of the local government. As long as the local government and authorities are present and still able to govern their area, the state of the national disaster status is unnecessary. In other words, to receive a national disaster status, there are many aspects to consider. The important aspect to define the status is the functionality of the local government and their capability to handle the disaster impacts with the help of BNPB or BNPB-D. However, until now there is no special Act or regulation that legally states that the functionality of the local government, even though implicitly the local government has to set the contingency plan for the disaster prevention, as the most important factor to define the national disaster status (Koenti, 2016).

Following the interview undertaken with Disaster Management Expert from ITB, it was revealed that since 2004 until now there have been no disasters that actually make the government fail to run its functions. Another interviewee, an expert of disaster management from Resiliency Initiative, also stated that national disasters have its scale and cannot be decided haphazardly since Indonesia has divided the levels of disaster starting from local, provincial, then national level. The most recent disaster that received a national disaster status was the Aceh Tsunami in 2004. On the other hand, according to the data of BNPB, there are approximately 1000 to 2500 disasters occurred each year. One of the disasters that occurred recently in August 2018 is the earthquake in Lombok that caused up to 7 trillion rupiahs loss which was larger compared to the economic loss during the tsunami Aceh with 4 trillion rupiahs loss (BNPB, 2018). However, the earthquake in Lombok was not defined as a national disaster since the local government was still able to respond to the impacts of the disaster with the review of the President of Indonesia. Also, the status of national disaster will have an impact on the number of tourists visiting Lombok and other tourism sectors in Indonesia. Following those facts, it could be concluded that the absence of national disaster status would add to the driven factors of the unusable tax incentives.

\section{Tax Incentive Policy Evaluation According to the Efficiency Criteria}

According to Dunn (2003), the efficiency criteria are required to understand how much effort is needed to achieve the expected outcomes. The measurement of efficiency is conducted by looking at the cost of taxation (load, effort, or cost) that should be borne by the taxpayer or government. For the government, the incurred fiscal cost is a result of the tax incentive policy on donation for disaster in the form of the loss of the potential government revenue (potential loss) or the tax expenditure for providing the incentive. The report on the amount of the tax expenditure has not been calculated in the taxation budget report released by the Fiscal Policy Office (Badan Kebijakan Fiskal or BKF) for the 2016-2017 periods due to the policy that has not been implemented as a result of the limited requirement for donation. Looking at the current condition where the citizens are willing to donate although they will not gain any benefit from such activity indicates that there are other external factors besides the incentive that has encouraged the corporates and the taxpayer to donate. The factors described in the DDTC Working Paper (2017:4) written by Darussalam and Kristiaji includes (1) Altruism behavior, this behavior put forward the moral responsibility by providing the needs of other members of the citizens; (2) Motivated by the desire to gain acknowledgment or credibility among the citizens; (3) Responsibility factor to practice the teaching of the religions.

For the taxpayer, the fiscal cost and time cost incurred as the consequence of applying tax incentive include the cost and time to follow the administration process such as the permit which is required for an institution to perform the collection and distribution of the donation for disaster victims. According to the Act No. 9 the year 
of 1961 on the Collection of Fund and Goods, the distribution of the donation can only be conducted by the institution that already has a permit, granted by the authority, where the collection of the donation is conducted. In the application of the permit, the institution should describe the objective and motive of the collection of the donation including the detail of the funding realization. If the permit has been granted, the institution will receive an approval letter, which is valid for three months. The institution who conduct the collection of donations without applying for the permit will receive a criminal sanction or penalty. Moreover, the institution has to report to the Ministry of Social and the Ministry can request for a financial audit by the public accountant.

Looking at the administration of the permit as mentioned above, the regulation has a function to ensure the certainty of the tax collection. The rigid administration will minimize the probability of the violation of the permit to collect the fund. Besides, it can help the government to monitor the collection and distribution of the funds by the institutions. Nevertheless, the administration of the permit is not a simple procedure since the institution should apply for the permit in a relatively short period that is once every three months. The short validity period of the permit could incur higher fiscal and time costs for the taxpayer.

The tax incentive policy on donation for disaster is considered inefficient without an effective policy evaluation. The objective of the policy is actually simply to improve the participation of the citizens. However, the administration procedure that should be followed by the taxpayer is often very rigid compared to the expected goal. Looking at the objective, the citizens' participation has increased but not because of the tax incentive policy. That means efficiency criteria is not fulfilled since the policy cannot be implemented so that its efficiency cannot be measured.

\section{The Tax Incentive Policy Evaluation on Donation for Disaster According to the Adequacy Criteria}

In the policy evaluation, the adequacy criteria are essential to understand whether expected outcomes could solve the problem. Assessing the adequacy, according to Dunn (2003) can be performed by looking at the background of the making of the policy and how the policy could handle the problem. Dunn (2003) also states that if a policy can run effectively and efficiently, there is a high probability that the policy is adequate. The fact that the policy cannot be used due to the status of the disaster and rigid process of applying tax incentives indicates that the adequacy criteria for the tax incentive policy on donation for disaster are not satisfied. The tax incentive on donation for disaster, which objective is to improve the citizen's participation, has not satisfied the needs of the targeted groups. During the last ten years of the implementation of the policy, the targeted groups of this policy were not able to access the tax incentive policy on donated funds. As mentioned previously, the citizens' participation to donate has increased each year, but the increase is not the result of the tax incentive policy but due to other external factors.

\section{The Tax Incentive Policy Evaluation on Donation for Disaster According to the Equity Criteria}

The equity criteria are essential to evaluate the policy on whether the benefit of the policy has been distributed evenly to different targeted groups. Generally, the tax incentive policy is provided for the parties participated in the donation for disaster, i.e. the institutions participated in the collection and distribution of the donation as well as the parties who donate for the disaster victims. As for the disaster victims, the donation received is not calculated as the income. However, the government usually released a tax incentive in the form of easier access to tax reporting administration for the victims of the disaster as stated in the regulation of the Directorate General of Taxes.

In order to evenly distribute the benefit of the tax incentive on donation for disaster to the targeted groups, socialization by the tax authority or the government is very important. Moreover, socialization also has an important role to ensure that the objective of the regulation released by the government can be achieved properly. From the in-depth interview, the Directorate General of Taxes states that they have conducted socialization, limited only to the representative of the groups that are the subject of the tax incentive. Meanwhile, from the perspective of the tax incentive subjects, they state that the government and the tax authority have not conducted any socialization 
of the tax incentive policy.

Without socialization, the citizens will not understand the tax incentive regulation. Regrettably, the tax incentive policy has not been socialized properly, despite the great potential of the philanthropic activities in Indonesia. The tax incentive could encourage the citizens' behavior to donate and eventually reduces the government's expenditure on disaster response. If the incentive could encourage the participation of the citizens, the government could focus more on other things, such as the economic recovery of the area affected by the disaster.

The description above concludes that the tax incentive policy on donation for disaster has not been distributed evenly among the related institutions as well as the citizens. This occurred as the result of poor socialization by the Directorate General of Taxes that leads to the poor understanding of the existence of the regulation. Sufficient socialization from the respective government body at least would add the understanding of the targeted party to the policy and the objective of the policy (Gillardi et. al, 2014). Considering the role of the tax incentive, the tax incentive for philanthropic activities can be utilized as an alternative source of funds outside the tax.

\section{The Tax Incentive Policy Evaluation on Donation for Disaster According to the Responsiveness Criteria}

The responsiveness criteria are used to evaluate whether the result of a particular regulation could satisfy the needs, preference or values of particular groups. Dunn (2003) mentioned that a regulation can be considered failed if it cannot respond to the actual needs of the targeted groups. Therefore, the philanthropic institutions that distribute donations, according to the author, should be the ones who benefit from the tax incentive regulation.

The tax incentive regulation on donation for disaster often receives negative responses from the targeted groups. The Association of the Indonesian Philanthropy assumes that the things that have led the tax incentive to receive negative responses, in general, is due to the small benefit of the incentive, the limited aspects that receive the tax reduction, and the requirement of the disaster status. List (2011) in Darussalam (2017) concludes that the behavior of donating is very elastic and influenced by the availability of the incentive from the government. Although regulation has a great benefit for the targeted groups, if the bureaucracy process is difficult, then it will only make the regulation ineffective. If the government does not change anything of the requirements for the incentive, the negative response will persist. The government could reduce the requirements for getting the incentive, for example by reducing the status of national disaster as the requirement or expand the tax incentive to the level of disaster as stated by the BNPB.

From the description above, the philanthropic tax incentive policy has generally received negative responses from the related stakeholders. The tax incentive policy on donation for disaster has not been able to satisfy the needs of the targeted groups since the tax incentive has not been able to meet the actual needs of the groups that should receive the benefit.

\section{Tax Incentive Policy Evaluation on Donation for Disaster According to the Appropriateness Criteria}

Dunn (2003) states that the appropriateness criteria in policy evaluation refer to the values or price of the objective of the program and the strength of the assumption that supports the objective. The expected outcomes of the tax incentive policy on donation for disaster are to improve the corporates and taxpayer's participation to donate to the disaster victims. However, the status of national disaster and the poor socialization of the regulation has become an obstacle to implement the policy and led to the poor understanding of the targeted groups i.e. the corporate and the taxpayers, on the existence of the regulation. If the targeted groups are not aware of the regulation, it will lead to the poor implementation of the regulation to reduce or tackle the problem. Eventually, the regulation will become ineffective and cannot be utilized.

Although the tax incentive policy is still unable to use, referring to the objective and the backgrounds of the policy, it could contribute to the social changes by improving the citizens' behavior to help the victims of disaster and reduce the government's burden. Although the fund reserved from the national budget is still able to cover the economic loss of the disaster, the government cannot always rely on this fund whenever a sudden 
disaster occurred and requires a large number of funds for disaster response. This condition will become worse if there is an urgency or immediate action that requires a lot of funds in other sectors. The tax incentive policy on the donation if directed properly could improve the distribution function so that the well-being of the citizens will increase in all layers of the society while reducing the economic disparity between groups of society. This is related to the concept of disaster funding, which focused on disaster response. Therefore, as already described above, if the tax incentive is directed properly, it could encourage more people to donate and reduce the burden of the national budget. The government could allocate the fund for disaster response to disaster mitigation funding. Disaster mitigation if managed properly could minimize the impact and risk of disaster while improving the preparedness of any disaster incident. There will be a decrease in the expenditure as the government relies on the disaster response fund from the corporate and the taxpayers who contribute through donations. Moreover, from the tax function perspective, the incentive could stabilize the economy by minimizing the economic loss if disaster risk management is handled comprehensively and thoroughly in each layer of society.

The facts and data presented above show that tax incentives itself could not be well-implemented if the prerequisite rules have not been adequately formulated to support the implementation of tax incentive. The government shall reconsider to revise the requirements to be eligible for applying tax incentives for donation or other charitable funding. Further, considering the inherent characteristic of tax incentive that is to reduce the burden of the targeted party, it means the procedure to apply the grant should not be too complex. Sufficient socialization is required to enable people to have enough understanding of the underpinning of the program. Thus, further development of the tax policy with regard to the incentives for donation might be considered the finding of this research, specifically for the respective Indonesian government body to make use of the budget allocates to support the program.

\section{Conclusions}

The analysis of the tax incentive policy on donation for disaster response, which is made based on the Act, reveals that the regulation on donation as a non-taxed object is valid for any type of disaster without limitation. However, there is no regulation for the donation from foreign countries for disaster response activities. Moreover, donations for disaster response can only receive a tax reduction if the disaster receives a national disaster status. In addition, not all donations distributed by the non-profit organization can receive a tax reduction. It is only a non-profit organization with a permit from an authorized institution to collect donations for disaster response can receive a tax reduction.

The tax incentive policy evaluation on donation for disaster response has not fulfilled the policy evaluation indicators released by William Dunn. From the effectiveness aspect, the requirements have limited the scope of donation for disaster since the incentive only applicable for national disaster status, thus limiting the effectiveness and the benefit of the policy. The policy also does not meet the efficiency criteria. Although there is an increase in citizens' participation to donate, it was not because of the tax incentive policy but due to other external factors. From the adequacy criteria, the ineffectiveness of the policy has also led to the inability to fulfill the needs of the targeted groups to access the incentive. In the equity criteria, the benefit of the policy has not been distributed to the targeted groups since there is no socialization from the government or the tax authority to introduce the objective and benefit of the tax incentive policy. In the responsiveness criteria, the policy has not fulfilled the needs of the targeted groups. The limited disaster status requirement to receive the incentive has prevented the targeted groups to access the benefit of the tax incentive policy. In the appropriateness criteria, the value of the tax incentive results cannot be measured since it has never been implemented properly. The incentive policy has become inappropriate since it was not properly implemented to fulfill the taxation functions.

Based on the results of research and analysis of tax incentive policy evaluations for donation of disaster management, one of the suggestions that can be made by government is that the government needs to do a study of the main requirements of the object of donations that can get tax incentives, which currently only aimed for disasters with national status. The tax incentive requirements can be done by lowering the disaster status. This is intended to capture all conditions of Indonesia with a 
high level of natural disasters. In addition, broader socialization also needs to be done to groups that are targeted by tax incentive policy, both companies and taxpayers, and institutions that play a role as a distributor of donations. This is intended so that the policy can be executed and functioning properly.

\section{References}

Abeler Johannes and Jager Simon (2015) Complex Tax Incentives, American Economics Journal: Economic Policy 7(3), pp. 1-28.

Blumenthal, Marsha, Kalambokidis, Laura, and Turk, Alex (2012), Subsidizing Charitable Contributions With a Match Instead of a Deduction: What Happens to Donations and Compliance?, National Tax Journal, 65:1, pp. 91-116. DOI:dx. doi.org/10.17310/ntj.2012.1.04.

BNPB (2018). Data Informasi Bencana Indonesia. Retrieved from Badan Nasional Penanggulangan Bencana: http://bnpb. cloud/dibi/laporan4

Brown, N. A., Rovins, J. E., Usdianto, B., Sinandang, K., Triutomo, S., Hayes. J. (2016). Indonesian Disaster Response Practices and Roles. New Zealand Ministry of Foreign Affairs and Trade, Wellington, New Zealand.

Charities Aid Foundation. (2018). CAF World Giving Index 2018. CAF Online Publication. Retrieved from https://www. cafonline.org/docs/default-source/aboutus-publication s/caf_wgi2018_report_ webnopw_2379a_261018.pdf.

Cropley, A. J. (2019, $2^{\text {nd }}$ updated, revised, and enlarged edition). Qualitative research methods: A practice-oriented introduction for students of psychology and education. Riga, Latvia: Zinātne. (open access - doi: 10.13140/RG.2.1.3095.6888)

Darussalam, \& Kristiaji, B. (2017). Insentif Pajak Untuk Kegiatan Filantropi.Jakarta: DDTC Working Paper.

Dunn, W. (2003). Public Policy Analysis: An Introduction Second Edition. New York: Pearson Education.

European Fundraising Association. (2018) Tax Incentives for Charitable Giving in Europe, retrieved from https://efa-net. eu/wp-content/uploads/2018/12/EFA-TaxSurvey-Report-Dec-2018.pdf.

Fack Gabrielle and Landais Camille, (2011) Charitable Giving and Tax Policy in the Presence of Tax Cheating: Theory and Evidence from the US and France, Working
Paper retrieved from http://piketty.pse. ens.fr/files/FackLandais2011.pdf.

Gillardi Fabrizio and Wassorfallen Fabio, (2014) How Socialization Attenuates Tax Competition, British Journal of Political Science 46(1), DOI: 10.1017/ S0007123414000246.

Heintze, H.-J. (2018). World Risk Report 2018. Berlin: Institute for International Law of Peace and Armed Conflict (IFHV). Retrieved from https://weltrisikobericht. de /english-2/.

Hickey R., Bradley Minaker B\& Payne A.A., (2019). "The Sensitivity of Charitable Giving to the Timing and Salience of Tax Credits," National Tax Journal, National Tax Association; National Tax Journal, vol. 72(1), pages 79-110, March 2019.

John R. Brooks, (2016) The Missing Tax Benefit of Donor-Advised Funds, Tax Notes, February, pp. 1013-1024, retrieved from https://scholarship. law.georgetown.edu/cgi/viewcontent. cgi ?article $=2674 \&$ context $=$ facpub

Koenti Ishviati Joenaini, (2016) Diskresi dalam Penanggulangan Bencana di DIY dengan Paradigma Kontijensi, Jurnal Hukum Ius Quia Iustum No. 3, Vol. 23, pp. 461-458.

Kurniati Chandara Puspita, (2015) A Study of Policies on Disaster Status Endorsement, Local Disaster Management Agency Institution, and Disaster-Related Aid Management Post Law No. 24 year 2007, Jurnal Tata Kelola \& Akuntabilitas Keuangan Negara Vol. 1 No. 1, pp 95-106.

Law No. 24 year 2007 concerning Disaster Management

Law No. 7 year 1983 lastly amended by Law No. 36 year 2018 concerning Income Tax.

Ministry of Finance Regulation No. 245/ PMK.03/2008 concerning Personal and Corporation Performing Small and Medium Scale Business and Receiving Donation, Grant and Fund Categorized as NonTaxable Objects

Ministry of Finance Regulation No. 76/ PMK.03/2011 concerning The Guideline of Recording and Reporting the Donation for National Disaster Management, R\&D Funding, Education Facilities Funding, Sports Development Funding and Donation for Social Infrastructure Establishment.

Newman, W.L. (2014) Social Research Methods: Qualitative and Quantitative Approach Seventh Edition, Edinburg: Pearson Education Limited.

OECD (2014) Fundamental Principle of Taxation, retrieved from https://www.oecd-ilibrary. org/docserver/9789264218789-5-en.pdf? 
expires $=1571568429 \& i d=i d \& a c c n a m e=g$ uest\&checksum $=$ CFE374541BC4C1DA2B2 53323880B498C

Redonda, Agustin \& Sarralde, Santiago \&Hallerberg, Mark \& Johnson, Lise\&Melamud, Ariel \&Rozemberg, Ricardo \& Schwab, Jakob \& Von Haldenwang, Christian. (2018). Tax expenditure and the treatment of tax incentives for investment. Economics: The Open-Access, Open-Assessment E-Journal. 10.5018/ economics-ejournal.ja.2019-12.

Rosdiana, H., \& Irianto, E. S. (2014). Pengantar IImu Pajak: Kebijakan dan Implementasi di Indonesia.Jakarta: Rajawali Pers.

Sari Nuraini, Dewi Maya Safira\& Sun Yen, (2015) Indonesia: The Effect of Tax Holiday on Economic Growth Related to Foreign Investment, Procedia - Social and Behavioral Sciences 211(2015), pp. 1008-1015

Schoenefeld Jonas and Andrew Jordan (2017)
Governing Policy Evaluation? Toward a New Typology, Evaluation, Vol. 23(3), pp 274-293,

The World Bank. (2012, November 12). Indonesia: Belajar dari Bencana. Retrieved from http://www.worldbank.org/in/news/ feature/2012/11/12/indonesia-learningfrom-disasters

United Nations (2018) Design and Assessment of Tax Incentives in Developing Countries, retrieved from https://www.un.org/esa/ $\mathrm{ffd} / \mathrm{wp}$-content/uploads/2018/02/taxincentives_eng.pdf

Wilson-Rogers Nicole and Pinto Dale, (2009) Tax Reform: A Matter of Principle? An Integrated Framework for the Review of Australian Taxes, e-Journal of Tax Research Vol. 1 No. 1,pp-72-105.

Yoon Sung-Soo, Seung-Weon Yoo \& Jinbae Kim (2011) Ambiguity, Audit Errors, and Tax Compliance, Asia-Pacific Journal of Accounting \& Economics, 18:1,pp. 11-26, DOI: $10.1080 / 16081625.2011 .9720871$. 